\title{
Q UARTERLY REVIEWS OF
}

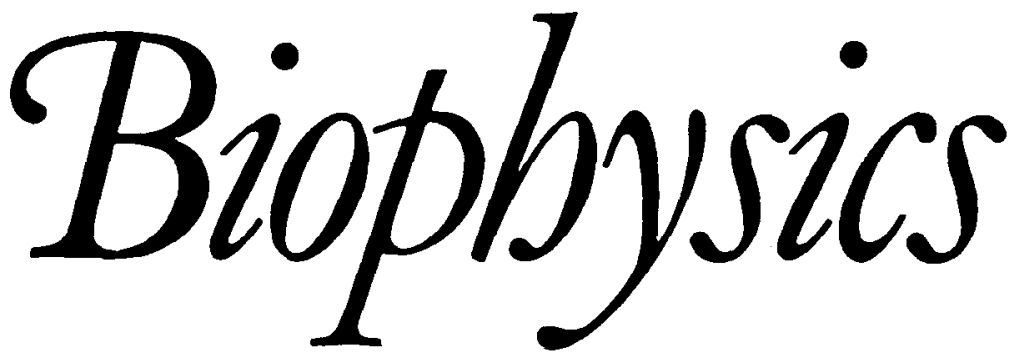

VOLUME 281995

EDITORS

C. Brändén (France)

D. M. Crothers (USA)

R. Henderson (United Kingdom)

C. Miller (USA)

\section{COUNCIL OF IUPAB}

H. J. C. BERENDSEN (The Netherlands)

\section{President}

M. BRUNORI (Italy) Honorary Vice President

C. R. CANTOR (USA)

M. CORTIJO (Spain)

J. GARNIER (France)

P. J. GARRAHAN (Argentina)

N. Go (Japan) Vice President

G. GoVIL (India)
J.N. JANSONIUS (Switzerland)

D.-C. LIANG (China)

A. C. T. NORTH (UK) Secretary General

F. G. PARAK (Germany)

D. A. D. PARRY (New Zealand) Vice President

I. PECHT (Israel)

R. RIGLER (Sweden)

A. B. RUBIN (Russia)

I. C. P. SMITH (Canada)

PUBLISHED FOR THE INTERNATIONAL UNION FOR

PURE AND APPLIED BIOPHYSICS

CAMBRIDGE UNIVERSITY PRESS 1995 
Published by the Press Syndicate of the University of Cambridge The Pitt Building, Trumpington Street, Cambridge CB2 IRP 40th West 20th Street, New York, NY $10011-4211$, USA 10 Stamford Road, Oakleigh, Melbourne 3166, Australia

(C) Cambridge University Press 1995

Printed in Great Britain by the University Press, Cambridge 


\section{CONTENTS}

NO. I FEBRUARY 1995

G. HALL. Silicon pixel detectors for X-ray diffraction studies at synchrotron sources

JANOS KIRZ, CHRIS JACOBSEN AND MALCOLM HOWELLS Soft

$\mathrm{X}$-ray microscopes and their biological applications

NO. 2 MAY I 995

J.-P. BENOIT AND J. DOUCET. Diffuse scattering in protein crystallography

R. HENDERSON. The potential and limitations of neutrons, electrons and $\mathrm{X}$-rays for atomic resolution microscopy of unstained biological molecules

z. SHAO AND J. YANG. Progess in high resolution atomic force microscopy in biology

NO. 3 AUGUST 1995

First Announcement: XIIth International Biophysics Congress

Travel fellowship programme for young scientists

DE WITT SUMNERS, CLAUS ERNST, SYLVIA J. SPENGLER AND NICHOLAS R. COZzARELLI. Analysis of the mechanism of DNA recombination using tangles

R. GRISSHAMMER AND C. G. TATE. Overexpression of integral membrane proteins for structural studies

NO. 4 NOVEMBER 1995

C. MONTECUCCO AND G. SCHIAvo. Structure and function of tetanus and botulinum neurotoxins

L. KESZTHELYI. Origin of the homochirality of biomolecules 